ORIGINAL ARTICLE / ARTIGO ORIGINAL

\title{
Lung cancer mortality trends in Mexico, 1998-2018: the impact of the General Law on Tobacco Control
}

\section{Tendências de mortalidade por câncer de pulmão no México, 1998-2018:0 impacto da Lei Geral de Controle do Tabaco}

\author{
Juan Alejandro Torres-Domínguez' (D), Alejandro Mohar Betancourt" (D), \\ Lina Sofía Palacio Mejíall' (D), Nancy Reynoso Noverón'v (1)
}

\begin{abstract}
Objective: The aim of this study was to describe trends in lung cancer (LC) mortality and trends in tobacco use. Methods: This is an ecological time-series study to determine mortality trends due to lung cancer resulting from tobacco consumption, based on secondary open-access sources, such as the National Surveys. Smoking prevalence, tobacco use trends, mortality rates, and percentage were determined by LC. The mortality trend from LC was calculated, and a linear regression analysis was performed to evaluate the impact of the General Law for Tobacco Control. Results: The prevalence of tobacco use decreased steadily between 1988 and 2015, particularly in men. Mortality rates and percentage decreased between 1998 and 2018. During this period, the mortality rate decreased from 6.3 to 5.4 per 100,000 population $(-0.032 / 100,000$ each year, $\mathrm{p}<0.001$ ), with a net decrease of 0.9 per 100,000 . We observe increases in mortality in women in the central and southeastern regions. Of 32 states, 18 showed a tendency to loss $(\mathrm{p}<0.005)$. The rate of change for men was -0.24 , with a total reduction of 2.17 before the introduction of the laws and -0.32 after their introduction, a total reduction of $3.24(\mathrm{p}<0.005)$. Women showed no reduction. Conclusions: Mortality rates showed a limited decrease. Strategies need to be strengthened, mainly in the central and southeastern regions, and to focus on the control of tobacco use by women.
\end{abstract}

Keywords: Epidemiology. Cancer of lung. Legislation, drug. Public policy

Universidad Nacional Autónoma de México, Facultad de Medicina, Programa de Maestría y Doctorado en Ciencias Médicas, Odontológicas y de la Salud - Ciudad de México, México.

"Universidad Nacional Autónoma de México, Instituto de Ciencias Biomédicas, Instituto Nacional de Cancerología, Unidad de Epidemiología e Investigación Biomédica en Cáncer - Ciudad de México, México.

"'Conacyt-Instituto Nacional de Salud Pública - Cuernavaca, México.

"VInstituto Nacional de Cancerología, Centro de Investigación y Prevención - Ciudad de México, México.

Corresponding author: Nancy Reynoso Noverón. Avenida San Fernando, 22, Col. Sección XVI, Del. Tlalpan, CEP:14080, Ciudad de México, México. E-mail: nrn231002@yahoo.com.mx

Conflict of interests: nothing to declare - Financial support: National Council of Science and Technology (CONACyT) for the scholarship and support provided for the development of this research (CVU: 896586) 
RESUMO: Objetivos: Descrever tendências na mortalidade por câncer de pulmão e no uso do tabaco. Métodos: Realizamos um estudo ecológico de séries temporais para determinar a tendência de mortalidade por câncer de pulmão de acordo com o consumo de tabaco, com base em fontes secundárias de acesso aberto, como as Pesquisas Nacionais. Prevalência de tabagismo, tendências de uso de tabaco, porcentagem e taxas de mortalidade foram determinadas pelo câncer de pulmão. A tendência de mortalidade por câncer de pulmão foi calculada e uma análise de regressão linear foi realizada para avaliar o impacto da lei geral para o controle do tabagismo. Resultados: A prevalência do uso de tabaco diminuiu continuamente entre 1988 e 2015, principalmente em homens. As taxas e percentuais de mortalidade diminuíram entre 1998 e 2018. Durante esse período, a taxa de mortalidade diminuiu de 6,3 para 5,4 por 100 mil habitantes (-0,032 por 100 mil a cada ano, $\mathrm{p}<0,001)$, com redução líquida de 0,9 por 100 mil. Observamos aumentos na mortalidade de mulheres nas regiões Centro e Sudeste. Dos 32 estados, 18 apresentaram tendência à perda $(\mathrm{p}<0,005)$. A taxa de mudança para os homens foi de $-0,24$, com redução total de 2,17 antes da introdução das leis e - 0,32 após a sua introdução - redução total de $3,24(\mathrm{p}<0,005)$. As mulheres não apresentaram redução. Conclusões: As taxas de mortalidade mostraram redução limitada. Estratégias precisam ser fortalecidas, principalmente nas regiões Centro e Sudeste, e deve-se enfocar o controle do uso do tabaco pelas mulheres.

Palavras-chave: Epidemiologia. Câncer de pulmão. Legislação de medicamentos. Política pública.

\section{INTRODUCTION}

Cancer has become one of the main causes of morbidity and mortality in the past decades ${ }^{1-4}$. Lung cancer (LC) is the most common cancer worldwide (except skin cancer), with 1,796 cases. In 2020,144 deaths were attributable to LC $(18 / 100,000 \text { population })^{5-7}$. Lung cancer (LC) was the fourth leading cause of death in Mexico in 2020 (7,100 deaths; $4.9 / 100,000$ inhabitants) 5 , with $90 \%$ of the deaths considered premature ${ }^{8-11}$, assuming that death occurred before reaching the average age, which, in Mexico, is considered $74-75$ years $^{12}$.

The incidence of LC has increased by $30 \%$ in the past 10 years. The main challenges for LC include late-stage diagnosis, lack of early detection strategies, poor training of primary care physicians, and lax enforcement of tobacco regulations, particularly in developing countries like $\mathrm{Mexico}^{13}$. Cases of LC and deaths can be prevented by smoking cessation, early detection, and timely treatment ${ }^{14,15}$.

The main risk factors include tobacco use, early age at onset, before age 14, length of time, and the number of cigarettes smoked ${ }^{16,17}$. Another risk factor is exposure to secondhand smoke ${ }^{18}$.

Other risk factors, not related to tobacco exposure, related to the incidence of LC are exposure to radon ${ }^{19}$, various occupational exposures including asbestos, diesel, and other substances and industrial activities ${ }^{20}$, chronic contact with wood dust or inhalation of firewood ${ }^{21}$ and environmental pollutants such as nitrogen oxides, ${ }^{22}$ sulfur oxides ${ }^{23}$ and particulate matter ${ }^{24}$, to a lesser extent, LC is also related to hereditary factors ${ }^{25,26}$. 
Tobacco use is directly associated with $85 \%$ of LC cases each year ${ }^{12}$. The problem of tobacco use and its mortality has become evident in recent years. Tobacco is responsible for at least 1.2 million deaths annually worldwide, of which $15 \%$ are related to $\mathrm{LC}^{27}$.

In the early 2000s, some studies revealed a significant positive correlation between smoking history and the trend in LC mortality rates in Mexico ${ }^{28,29}$.

Since the beginning of the new century, new laws on tobacco control have been enacted and the World Health Organization (WHO) Framework Convention on Tobacco Control has been signed. In 2008, the General Tobacco for Control Law (GLTC) was approved at the national level, aiming at protecting public health from the harmful effects of tobacco ${ }^{30}$.

The main actions of the GLTC in Mexico are to establish 100\% smoke-free spaces, evaluate the manufacture of tobacco products, place warning signs where there is sale of tobacco products, establish warning pictograms, establish import guidelines, promote participation in anti-smoking programs, and propose new public policies for the control of tobacco and its products based on scientific evidence and the determination of health risk ${ }^{31}$.

It has been shown that anti-tobacco policies can reduce tobacco use, the number of daily users, premature deaths, and deaths related to chronic diseases ${ }^{32}$.

However, the GLTC has not been fully evaluated after 10 years of its implementation.

This study aims to describe trends in mortality from LC and trends in tobacco use, the number of daily and occasional users, and intensity. It also aimed to examine national, regional, and state changes in LC mortality trends and evaluate the impact of the GLTC before and after its implementation in Mexico $^{32,33}$.

\section{METHODS}

This is an ecological time-series study to determine LC mortality trends according to tobacco consumption, based on secondary open-access sources, such as the National Survey of Addictions (ENA, 1988, 1993, 1998, 2002) ${ }^{34-36}$, National Health Survey (ENSA 2000) ${ }^{37}$,

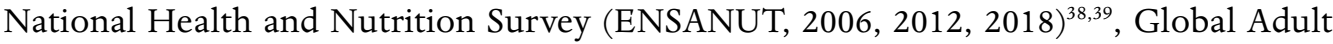
Tobacco Consumption (GATS, 2009, 2015) $)^{40,41}$, and National Survey on Drug, Alcohol and Tobacco Consumption (ENCODAT, 2008, 2011) ${ }^{42,43}$. All the surveys come from a national representative sample with disaggregation at the state level and present similar summary statistics, making it possible to link and compare them; however, there are few similar variables between them, which limits the scope of this study. Likewise, there are confounding variables that could not be considered.

LC mortality trends were determined using data from the National Institute of Statistics and Geography (INEGI). The quality of the information was evaluated. The rate estimates were calculated based on population projections of the National Population Council (CONAPO, 1998, 2018) by year, country, state, and regions (north, center, center-west, and southeast, ENSANUT). Men and women above 18 years who died from 1998 to 2018 due to LC (ICD-10: C34) were included. 
The mortality records of Mexico are collected by the General Directorate of Epidemiology, reviewed and confirmed by the National Institute of Geography, and further reviewed three times by trained personnel, doctors, epidemiologists, and statisticians, being the ones used for this study.

The quality of the information was verified by identifying the person who had registered the death, if it had occurred in a hospital or home, and the entitlement.

The differential diagnoses of LC as well as ICD-10 R840-R849 were reviewed. Fewer than 20 cases of ill-defined causes were identified in the study period; therefore, these were not redistributed.

The prevalence of smoking was determined based on the number of active smokers at the time of the survey, the number of cigarettes smoked by daily and occasional smokers, and the surveys based on when they were conducted. Using this data, we calculate state and national trends in tobacco use.

Mortality percentages and standardized rates were estimated indirectly by age, sex, state, and region in order to calculate LC mortality trends. Using data from INEGI, such as total deaths and sex-adjusted rates from 1998 to 2018, we determined the change points in LC mortality. The implementation of the GLTC in 2008 was established as a point of comparison, with May 30, 2008, being the date of publication in the official gazette of the federation in Mexico ${ }^{31}$.

The relationship between tobacco use and LC mortality was defined in two ways, based on the public literature and indirectly through the trend of tobacco use reported in national surveys and cancer mortality rates from lung in the same period of time.

Due to the presence of carcinogenic substances in tobacco, including benzene, nitrosamine, formaldehyde, and acetaldehyde, consumption of tobacco is not safe.

Using linear regression models, we calculated whether the decrease during the period was statistically significant. Linear regression was used to determine the trend of mortality, as well as to predict the behavior of rates and percentages. The assumptions of linearity, independence, homoscedasticity, normality, and noncollinearity were verified.

The annual and period change rate was used to identify the speed of reduction in mortality rates by sex.

Statistical analysis was performed using Excel 2013 and Stata version 14.2.

\section{RESULTS}

The prevalence of tobacco use showed a decrease from 1988 to 2015. Considering both sexes, we observed a net decrease of $9.4 \%$ in 27 years, from $25.8 \%$ in 1988 to $16.4 \%$ in 2015 , with an average annual decrease of $0.9 \%$. The greatest decrease was recorded in 2000 and 2006 (-5.4 and $-7.5 \%$, respectively). However, large increases were observed in 2008 and 2011 (1.5 and 5.8\%, respectively) (Figure 1).

The prevalence of male daily smokers decreased from $21.6 \%$ in 2006 (ENSANUT, 2006) to $11.9 \%$ in 2015 (GATS, 2015). Women only showed a decrease of $2.9 \%$, from $6.5 \%$ in 2006 


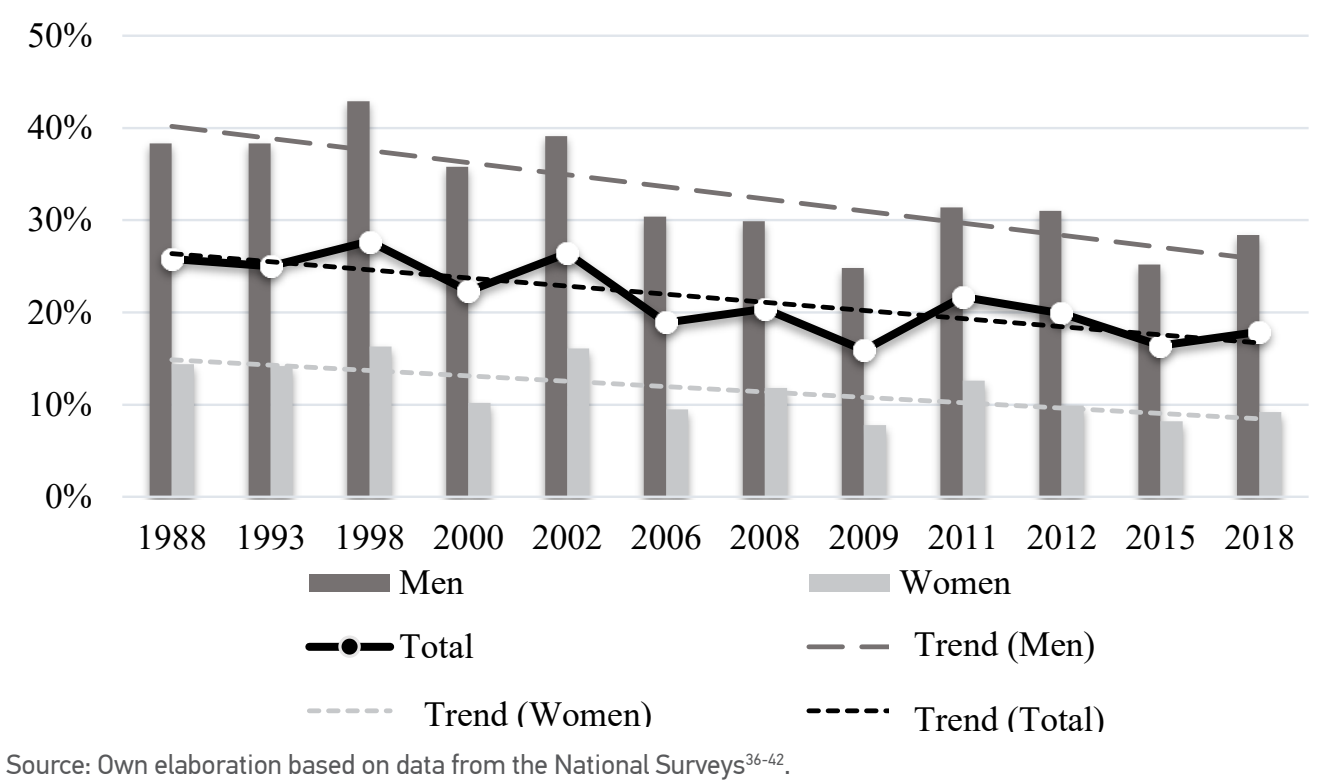

Figure 1. Trend in the percentage of tobacco consumption in Mexico, both sexes, over 18 years of age, 1988-2018.

to $3.6 \%$ in 2015 . Tobacco use and daily smoking showed a slight downward trend from 1988 to 2016 . Occasional smoking remained at $10 \%$ on average, $14.8 \%$ for men and 5.5 for women. The average number of cigarettes smoked daily has remained the same since 2000 : seven cigarettes (median 7; interquartile range [IQR] 6-8).

In 1998, LC accounted for $1.4 \%$ of all deaths, compared to $1.2 \%$ in 2008 and $1.0 \%$ in 2018, with an average annual decrease of $0.02 \%(\mathrm{p}<0.01)$. A decrease in LC mortality rates and percentages was identified between 1998 and 2018. The mortality rate was 6.3 in 1998, with a decrease from 2008 to 5.4 deaths per 100,000 in 2018. This represents an annual decrease of 0.032 per 100,000 inhabitants $(\mathrm{p}<0.01)$, with a net decrease of 0.9 per 100,000 (Figure 2).

The states with the lowest mortality rates are Quintana Roo (2.4), Tlaxcala (2.6), Oaxaca (3.0), and Chiapas (3.0). Those with the highest rates are Chihuahua (10.5), Sonora (12.2), Sinaloa (11.6), and Baja California Sur (10.5). The last three states have shown the highest rates than in the past two decades. Only four states had rates of more than 10 deaths per 100,000 residents in 2008 .

The northern region showed a decrease compared to the central and southeastern states, which had constant increases, particularly in Mexico City (8.2), the State of Mexico (3.2), and Chiapas (3.0) (Figure 3).

The northern region and Mexico City had the highest rates, while the southeast region showed rates below 5 deaths per 100,000 inhabitants $^{8-12}$. In 2008 , only four states (three from the north and one from the center-west of Mexico) had rates higher than 8 (Figure 3 ). 


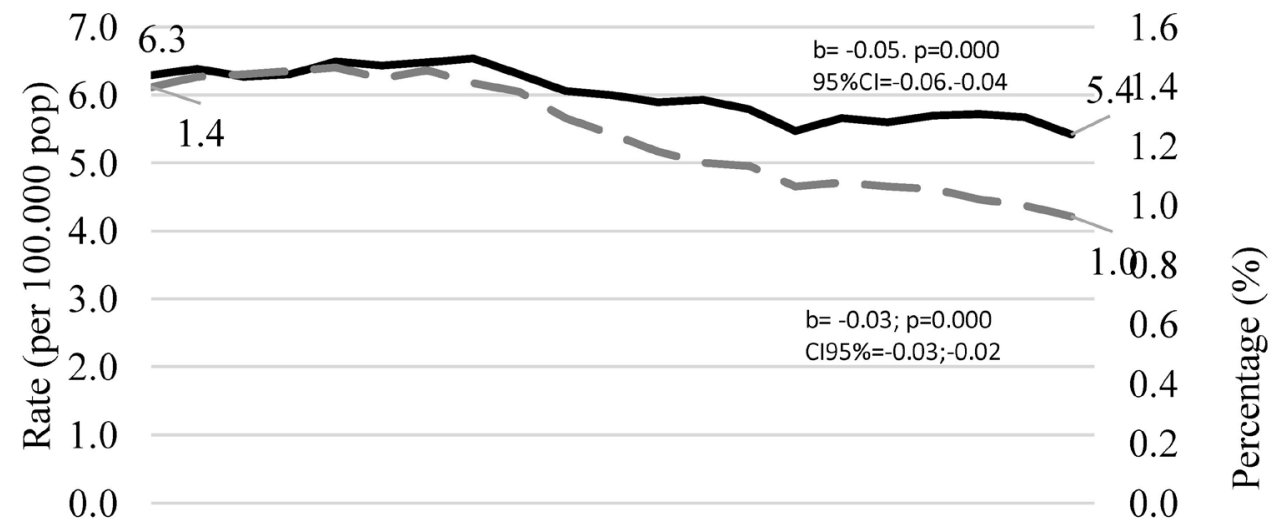

19982000200220042006200820102012201420162018

Año

- Tasa —- Percentage

Source: Own elaboration based on mortality data from INEGI 1998-2018, CONAPO forecast for 2050.

Figure 2. Lung cancer mortality rate per 100,000 population and percentage of deaths attributable to lung cancer, all ages, both sex, Mexico 1998-2018.

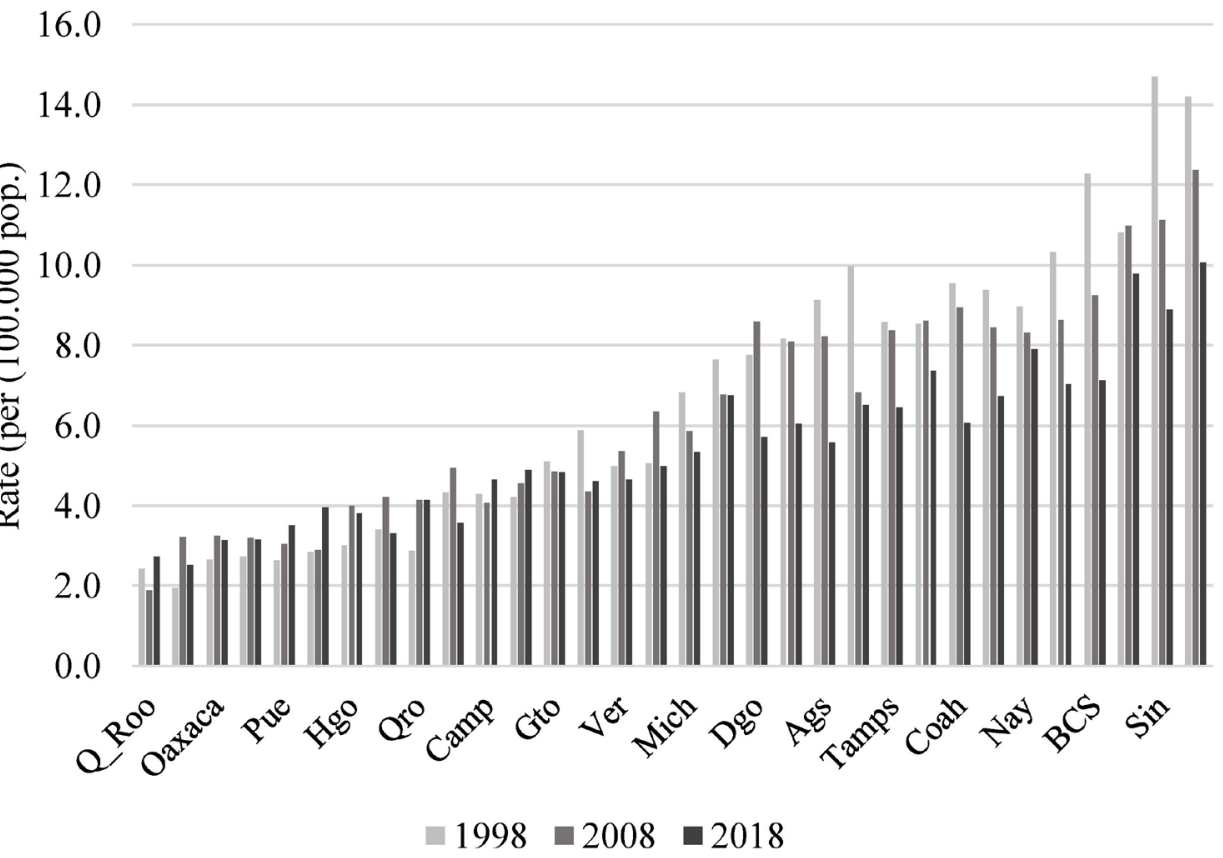

Source: Own elaboration based on mortality data from INEGI1998-2018, CONAPO forecast for 2050

Figure 3. Lung cancer mortality rate by states, Mexico 1998 (8.3), 2008 (7.8), 2018 (5.4). Both sex, over 18 years, per 100,000 population. 
Men showed a downward trend in 31 states $(\mathrm{p}<0.0001)$. Throughout the period, the northern states showed high rates, but with a decline. West-central Mexico also showed a decrease, unlike central and southeastern Mexico, where only a slight decrease was found or, conversely, an increase was reported in some parts. The decline was even greater after 2008 in all states, with larger and faster declines (Table 1).

Women showed a different trend. The north and central-west of Mexico showed a downward trend with a greater decrease as of 2008, while the central and southeast of Mexico exhibited fluctuations throughout the period. Of 32 states, 18 showed a downward trend $(\mathrm{p}=0.0194)$ (Table 1$)$.

We use a junction point regression model to assess changes in mortality trends by sex over time. Age-adjusted rates were calculated for those above 18 years of age. After a decline in 2005, men showed an increasing trend in 2012. Before the implementation of GLTC, the annual rate of change was -0.24 per 100,000 population, with a net decrease of 2.17 . Later, it accelerated and reached -0.32 per 100,000 inhabitants, with a net reduction of $3.24(\mathrm{p}<0.05)$.

We observe more changes in women, particularly in 2004 and 2012. The change was minimal $(-0.05)$ before the GLTC and nonexistent after it. The net change was 0.74 before GLTC and 0.02 after GLTC ( $\mathrm{p}>0.05$ ) (Figure 4).

In this study, smokers are five times more likely to die from LC than nonsmokers $(95 \%$ CI: $1-8 ; p=0.007)$. The impact of the GLTC is clear when we look at how quickly deaths

Table 1. Mortality rate by sex and region, Mexico 1998-2018 (age-adjusted, per 100,000 older than 18 years).

\begin{tabular}{l|c|c|c}
\multicolumn{1}{l|}{ Region } & Coefficient & $95 \%-\mathrm{Cl}$ & p-value \\
\hline Men & \multicolumn{3}{|c}{} \\
\hline National & -0.31 & $(-0.34 ;-0.28)$ & 0.000 \\
\hline Northern & -0.66 & $(-0.72 ;-0.60)$ & 0.000 \\
\hline Central-West & -0.53 & $(-0.60 ;-0.46)$ & 0.000 \\
\hline Central & -0.09 & $(-013 ;-0.05)$ & 0.000 \\
\hline Southeastern & -0.21 & $(-0.26 ;-0.17)$ & 0.000 \\
\hline Women & & & \\
\hline National & -0.04 & $(-0.05 ;-0.03)$ & 0.000 \\
\hline Northern & -0.1 & $(-0.14 ;-0.05)$ & 0.000 \\
\hline Central-West & -0.11 & $(-0.15 ;-0.08)$ & 0.000 \\
\hline Central & 0.02 & $(0.004 ; 0.04)$ & 0.021 \\
\hline Southeastern & 0.002 & $(-0.02 ; 0.02)$ & 0.868 \\
\hline
\end{tabular}

Source: Own elaboration based on mortality data from Instituto Nacional de Estatística e Geografia 1998-2018, Consejo Nacional de Población forecast for 2050. 




Source: Own elaboration based on mortality data from INEGI 1998-2018. CONAPO forecast for 2050

Figure 4. Linear regression in the trend of standardized mortality rates for lung cancer in Mexico, by sex, over 18 years, 1998-2018 (rate per 100,000 population).

decreased after it went into effect. The decrease was evident in men, unlike women who showed strong spikes that minimize the effects of the law.

\section{DISCUSSION}

Lung cancer continues to be one of the most common cancers affecting the Mexican population. The number of cases and deaths associated with tobacco use is expected to increase ${ }^{44}$.

The prevalence of tobacco use has decreased in the past decades, especially in men. Death rates fell slightly, particularly after 2008, when only four states had rates of more than 10 deaths per 100,000 residents. However, the observed decline in women was offset by some increases in the early 2010s. Mexico has a mixed pattern that varies by gender and region.

Dela Cruz et al. revealed that LC is the leading cause of death among men and women worldwide and these cases have increased by $49.9 \%$ in developing countries ${ }^{10}$.

The changes in prevalence before 2008 may be due to the international tobacco control strategies that gradually permeated the country until the national and state laws were finalized, mainly focused on controlling the advertising and sale of tobacco in points close to schools the metropolises ${ }^{30}$.

Based on a report by Groot et al. ${ }^{15}$, incidence and mortality rates are declining in the United States. They asserted that this decline is due to decades of education and public policy and strategies focused on tobacco control. However, various parts of the world are experiencing an increase.

Several factors are associated with increasing or decreasing rates. Geography is a key factor; in Europe, LC in women exceeded breast cancer (14.6 and 14 cases per 100,000 inhabitants, respectively), while in Asia, pollution and occupational exposure play an important role. 
The early age of initiation of tobacco use is an important risk factor. Therefore, if strategies are not implemented to discourage young people, the LC epidemic will not diminish ${ }^{14,15}$.

The U.S. Centers for Disease Control and Prevention reported in 2018 that $15.6 \%$ of men and $12 \%$ of women used tobacco on a daily basis. The prevalence was higher in the age group 25-44 years (16.5\%) and in people with the lowest socioeconomic level46.

Although the number of male users has decreased by 60 million worldwide in the past two decades, we are far from reaching the global goal ${ }^{3}$.

Tobacco use among men has decreased in Mexico, but has increased among women, particularly in central and southeastern Mexico. LC mortality rates showed a similar trend ${ }^{45,46}$.

The study period 2008 to 2018 is limited to establish reliably the impact of the law on mortality from LC; however and in a preliminary way, it allows to evaluate and glimpse a pattern in the behavior of mortality, in order to restructure and strengthen the strategies.

The ecological fallacy, aggregation bias, multicollinearity, and effect by specific groups are limitations inherent to ecological studies; however, when wanting to observe the effect and impact of the application of a health law and strategy at the national level, this type of the study allows, even with all the limitations, to determine its tendency to strengthen tobacco control in specific groups and impact mortality from LC.

The effect that the GLTC had on mortality trends is striking when we look at the rate at which LC deaths decreased in the country after the law went into effect. In 2011, tobacco advertising, promotion, and sponsorship were banned at the national level in the main media, which maintained the downward trend in tobacco use $\mathrm{e}^{47}$ to social and psychological factors, as well as to marketing and advertising campaigns directed directly at women ${ }^{48}$.

This explains the lack of effectiveness of the GLTC. While the law proved effective in certain groups, the tobacco industry and society alike have refocused their strategies to promote tobacco use, thus nullifying the benefits of anti-tobacco policies.

The impact of the law must be evaluated in a disaggregated manner. When we analyze the data by specific regions, we find that the northern region lacks state regulations to control tobacco use or smoke-free environments ${ }^{49}$. Although some states are about to issue such regulations, it is said that people above 45 years of age live "A life of smoking." Another explanation is the proximity to the border and the illicit cigarette trade. Mexican Americans are reported to be more likely to use tobacco. ${ }^{50}$

In contrast, most central states have regulations, but their rates, while still low, are increasing. This could be explained by lax law enforcement, lack of social cohesion, and high population density. Rosario-Tapia stated that smoking is associated with living in urban areas ${ }^{36}$.

Therefore, it is convenient to delve into the factors associated with the reduction in the number of deaths from LC, whether they are public policies or improvements in screening, diagnosis, and treatment. Despite the good results of the GLTC, such as the decrease in the number of cases, deaths, and smokers, several factors have increased these same numbers and have mitigated the positive effects of the law ${ }^{51}$.

Since 2002, Mexico has implemented strategies to control tobacco use; it has also acceded to the WHO Framework Convention since its promulgation. The most effective strategies for 
tobacco control focus on increased taxes; rigorous advertising, promotion, and sponsorship; warnings of the dangers of tobacco; and establishment of smoke-free spaces; the increase in tobacco taxes can decrease the tobacco epidemic and consequently reduce LC mortality in Mexico ${ }^{52-54}$.

Brazil is an example of countries in the region that present the greatest reductions in the prevalence of smoking and with broader tobacco control policies worldwide, where reductions of $6 \%$ in the prevalence of tobacco use are observed in 8 years ${ }^{55}$.

Mexico has also drafted and approved regulations since 2008. In that same year, mortality rates began to decline, and the downward trend continues to this day, possibly due to the impact of international strategies that impacted and promoted the generation of national and state laws. However, the effects have not been as promising as in other areas. Therefore, it is necessary to review and strengthen the strategies, especially in the central and southeastern states where LC mortality rates show a constant and significant increase among women.

\section{REFERENCES}

1. Soto-Estradaa G, Moreno-Altamiranoa L, Pahua DD. Epidemiological overview of Mexico's leading causes of morbidity and mortality. Rev Fac Med UNAM 2016; $59(6): 8-22$.

2. Gómez Dantés H, Castro MV, Franco-Marina F, Bedregal P, García JR, Espinoza A, et al. Burden of disease in Latin America. Salud Publica Mex 2011; 53 (Suppl 2): s72-7. PMID: 21877095

3. Ferlay J, Soerjomataram I, Ervik M, Dikshit R, Eser S, Mathers C, et al. GLOBOCAN 2012: Estimated Cancer Incidence, Mortality and Prevalence Worldwide in 2012 v1.0: IARC CancerBase No. 11. Geneva: World Health Organization; 2012 [cited on Jan 12, 2018]. Available at: http:/ / globocan.iarc.fr/Default.aspx

4. World Health Organization, International Agency for Research on Cancer. The Globocan Project. Geneva: World Health Organization; 2012 [cited on Fev 12, 2018]. Available at: http:/ / globocan.iarc.fr/Default.aspx

5. World Health Organization, International Agency for Research on Cancer. Cancer fact sheets. Lyon: World Health Organization, Global Cancer Observatory; 2020.

6. The Globocan Cancer Observatory. All cancers. Lyon: International Agency for Research on Cancer; 2020 [cited on Set 19, 2019]. Available at: https: / /gco.iarc.fr/today/ data/factsheets/cancers/39-All-cancers-fact-sheet.pdf

7. The Globocan Cancer Observatory. Mexico. Lyon: International Agency for Research on Cancer; 2020 [cited on Set 19, 2019]. Available at: https: / gco.iarc. $\mathrm{fr}$ / today/data/factsheets / populations / 484-mexicofact-sheets.pdf
8. Reynales-Shigematsu LM. Tobacco and cancer: epidemiology and new perspectives of prevention and monitoring in Mexico. Salud Publica Mex 2016; 58 (2): 251-60. https: / / doi.org/10.21149/spm.v58i2.7794

9. Aguilar F. Llega 98\% de pacientes con cáncer de pulmón en etapa avanzada [Internet]. The sun of Mexico. 2016 [cited on Feb 28, 2019]. Available at: https:// www.elsoldemexico.com.mx/mexico/Llega-98-depacientes-con-c\%C3\%A1ncer-de-pulm $\% \mathrm{C} 3 \% \mathrm{~B} 3 \mathrm{n}$ en-etapa-avanzada-173565.html

10. Dela Cruz CS, Tanoue LT, Matthay RA. Lung cancer: epidemiology, etiology, and prevention. Clin Chest Med 2011; 32 (4): 605-44. https: / / doi.org/10.1016/j. ccm.2011.09.001

11. The Globocan Cancer Observatory. Global cancer. Lyon: International Agency for Research on Cancer; 2018.

12. Instituto Nacional de Estadística y Geografía. Esperanza de vida¿Te has preguntado cuántos años podrías llegar a vivir? [internet]. 2019 [cited on Oct 21, 2021] Available at: http: / / cuentame.inegi.org.mx/poblacion/esperanza.

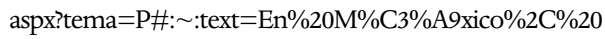
la\%20esperanza\%20de,2019\%20es\%20de $\% 2075 \%$ $20 \mathrm{a} \%$ C3\% B1os.)

13. Secretaría de Salud México. Cada año mueren cerca de ocho mil mexicanos por cáncer de pulmón: El 85 por ciento de los casos de esta enfermedad está relacionado directamente con el consumo de tabaco [Internet]. 2018 [cited on March 18, 2020]. Available at: https:/ / www.gob.mx/salud/prensa/145-cada-anomueren-cerca-de-ocho-mil-mexicanos-por-cancer-depulmon?idiom=es\#: : text=145.,Salud $\% 20 \% 7 \mathrm{C} \% 20$ Gobierno\%20\%7C\%20gob.mx 
14. American Cancer Society. Estadísticas importantes sobre el cáncer de pulmón [internet]. Cancer.org; 2020 [cited on May 6, 2020]. Available at: https://www. cancer.org/es/cancer/ cancer-de-pulmon/acerca/ estadisticas-clave.html.

15. Groot PM, Wu CC, Carter BW, Munden RF. The epidemiology of lung cancer. Transl Lung Cancer Res 2018; 7 (3): 220-33. https://doi.org/10.21037/ tlcr.2018.05.06

16. Stellman SD, Takezaki T, Wang L, Chen Y, Citron ML, Djordjevic MV, et al. Smoking and lung cancer risk in American and Japanese men: an international case-control study. Cancer Epidemiol Biomarkers Prev 2001; 10 (11): 1193-9. PMID: 11700268

17. Remen T, Pintos J, Abrahamowicz M, Siemiatycki J. Risk of lung cancer in relation to various metrics of smoking history: a case-control study in Montreal. BMC Cancer 2018; 18 (1): 1275. https:/ / doi.org/10.1186/ s12885-018-5144-5

18. Kim CH, Amy Lee YC, Hung RJ, McNallan SR, Cote ML, Lim WY, et al. Exposure to second-hand smoke and lung cancer by histological type: a joint analysis of the International Lung Cancer Consortium (ILCCO). Int J Cancer 2014; 135 (8): 1918-30. https: / / doi.org/10.1002/ijc. 28835

19. Melloni BB. Lung cancer in never-smokers: radon exposure and environmental tobacco smoke. Eur Respir J 2014; 44 (4): 850-2. https:// doi. org/10.1183/09031936.00121314

20. Gustavsson P, Jakobsson R, Nyberg F, Pershagen G, Järup L, Schéele P. Occupational exposure and lung cancer risk: a population-based case-referent study in Sweden. Am J Epidemiol 2000; 152 (1): 32-40. https: / / doi.org/10.1093/aje/152.1.32

21. Agencia EFE. Señalan riesgo de cáncer por inhalar humo de leña en zonas rurales de México [Internet]. EFE Agency. 2018 [cited on March 20, 2020]. Available at: https: / /www.efe.com/efe/america/mexico/ senalan-riesgo-de-cancer-por-inhalar-humo-lena-enzonas-rurales-mexico/50000545-3742941

22. Raaschou-Nielsen O, Andersen ZJ, Hvidberg M, Jensen SS, Ketzel M, Sørensen M, et al. Lung cancer incidence and long-term exposure to air pollution from traffic. Environ Health Perspect 2011; 119 (6): 860-5. https: / / doi.org/10.1289/ehp. 1002353

23. Pope CA 3rd, Burnett RT, Thun MJ, Calle EE, Krewski D, Ito K, et al. Lung cancer, cardiopulmonary mortality, and long-term exposure to fine particulate air pollution. JAMA 2002; 287 (9): 1132-41. https: / / doi.org/10.1001/ jama.287.9.1132

24. American Lung Association. The connection between lung cancer and outdoor air pollution [internet]. 2016 [cited on May 6, 2020]. Available at: https://www. lung.org/blog/lung-cancer-and-pollution.

25. Lichtenstein P, Holm NV, Verkasalo PK, lliadou A, KaprioJ, Koskenvuo M, et al. Environmental and heritable factors in the causation of cancer--analyses of cohorts of twins from Sweden, Denmark, and Finland. N Engl J Med 2000; 343 (2): 78-85. https://doi.org/10.1056/NEJM200007133430201

26. Kanwal M, Ding XJ, Cao Y. Familial risk for lung cancer. Oncol Lett 2017; 13 (2): 535-42. https: / / doi.org/ 10.3892/ ol.2016.5518

27. World Health Organization. World no tobacco day 2019: don't let tobacco take your breath away. Geneva: World Health Organization; 2019.

28. Tovar-Guzmán VJ, Barquera S, López-Antuñano FJ. Tendencias de mortalidad por cánceres atribuibles al tabaco en México. Salud Publica Mex 2002; 44 (Suppl 1): S20-8. PMID: 12055740

29. Rojas-Martínez R, Escamilla-Núñez C, Meza R, Vázquez-Salas RA, Zárate-Rojas E, Lazcano-Ponce E. Mortalidad por cáncer de pulmón en México de 1990 a 2016: efecto edad-periodo-cohorte. Salud Publica Mex 2019; 61 (3): 230-9. https: / doi.org/10.21149/9962

30. Monteverde HR, Monteverde TMR, Cordero RA. Impacto de las políticas antitabaco en México. Rev Fac Med UNAM 2011; 54 (5): 22-33.

31. Gobierno de México. Cámara de diputados del h. congreso de la unión. Ley general para el control del tabaco de May 30, 2008. México, 2008.

32. Valdés-Salgado R, Ávila-Tang E, Stillman FS, Wipfli $\mathrm{H}$, Samet JM. Leyes que prohíben fumaren espacios cerrados en México. Salud Pública de México 2008; 50 (Suppl 3): S334-42.

33. World Health Organization. WHO framework convention on tobacco control. framework agreement. Report No. 924359101 0. Geneva: World Health Organization; 2003 [cited on Set 20, 2019]. Available at: chrome-extension:// efaidnbmnnnibpcajpcglclefindmkaj/viewer.html?pdfurl $=$ http $\% 3 \mathrm{~A} \% 2 \mathrm{~F} \% 2$ Fapps.who.int $\% 2$ Firis $\% 2$ Fbitstream \%2Fhandle\%2F10665\%2F42811\%2F9241591013.pdf\% 3Bjsessionid\%3D381A6770BEEB2719E5D27183981BD 157\%3Fsequence\%3D1 \&clen=555496\&chunk=true

34. Gobierno de México. Cámara de Diputados del H. Congreso de la Unión. Reglamento de la Ley General para el control del tabaco. May 31, 2009. México, 2009.

35. Tapia-Conyer R, Medina-Mora ME, Sepúlveda J, De la Fuente R, Kumate J. La encuesta nacional de adicciones de México. Salud Publica Mex 1990; 32 (5): 507-22. PMID: 2089626

36. Tapia-Conyer R, Kuri-Morales P, Hoy-Gutiérrez MJ. Panorama epidemiológico del tabaquismo en México. Salud Publica Mex 2001; 43 (5): 478-84. PMID: 11763695 
37. Gobierno de México. National Institute of Statistics, Geography and Informatics. Encuesta Nacional de Adicciones 2002 (ENA 2002) [Internet]. 2002 [cited on July 10, 2020]. Available at: https:// www.gob.mx/salud/conadic/documentos/ encuesta-nacional-de-adicciones-2002-ena-2002

38. National Institute of Public Health. National health survey 2000: national survey. Morelos: INSP-SSA; 2003.

39. National Institute of Public Health. National survey of health and nutrition 2006: national survey. Morelos: INSP-SSA; 2006.

40. National Institute of Public Health. National health and nutrition survey 2012: national survey. Morelos: INSP-SSA; 2012.

41. National Institute of Public Health. Global survey of smoking in adults, Mexico 2009: global survey. Morelos: SSA-INSP-CONADIC-OPS-CDC-GTSS-MPOWER; 2010.

42. National Institute of Public Health. Global survey of smoking in adults. Mexico 2015: global survey. Morelos: SSA-CONADIC-INSP-DGE-PAHO-WHO; 2017.

43. National Institute of Public Health. National Survey of Addictions 2008: national survey. Cuernavaca, Morelos, Mexico: CONADIC-INPRF-INSP-FGRA; 2008.

44. Ramón de la Fuente Muñiz National Institute of Psychiatry. National survey of addictions 2011: tobacco report. National Survey. Mexico City: CENADICCONADIC-INPRFM-INSP; 2012.

45. World Health Organization, Jim Holmes. Ten facts about the tobacco epidemic and global tobacco control [internet]. Geneva: World Health Organization; 2020 [cited on Oct 1, 2020]. Available at: https:// www.who.int/features/factfiles/tobacco_epidemic/ tobacco_epidemic_facts/en/

46. World Health Organization. Data and numbers [internet]. Geneva: World Health Organization; 2019 [cited on Set 19, 2019]. Available at: https:// www.who.int/features/factfiles/tobacco_epidemic/ tobacco_epidemic_facts/en/.

47. Center for Disease Control and Prevention. Burden of tobacco use in the United States [internet]. Washington: Center for Disease Control and Prevention; 2020 [cited on Jul 26, 2020]. Available at: https: / / www.cdc.gov/ tobacco/campaign/tips/spanish/acerca/Carga-delconsumo-de-tobaco-en-los-Estados-Unidos.html

48. World Health Organization. World trend report on tobacco consumption [internet]. Geneva: World Health Organization; 2019 [cited on Jul 26, 2020]. Available at: https: / / www.who.int/es/news-room/ detail/19-12-2019-who-launches-new-report-on-globaltobacco-use-trends\#: :text=Seg\%C3 \% Bn\% 20el\% 20World Report $\%$ 20\% 20de, in\% 202018\% 2C\% 20lo\% 20which\% 20 assumes.

49. National Institute of Public Health. Prohibition of advertising, promotion and sponsorship of tobacco [internet]. 2020 [cited on April 16, 2021]. Available at: https: / / www.insp.mx/avisos / 4575-epidemia-tabacoprohibicion.html

50. World Health Organization. Ten facts about gender and tobacco [internet]. Geneva: World Health Organization; 2012 [cited on Jan 6, 2020]. Available at: https: / / www. who.int/features/factfiles/gender_tobacco/facts/es /

51. Codex. Communication, dialogue and awareness SC Anti-smoking legislation. [internet]. 2017 [cited on Jul 26, 2020]. Available at: https: / / codicesc.com/page/ 2 /

52. Pan American Health Organization. Medidas efectivas para el control del tabaco [internet]. Geneva: World Health Organization; 2020. [cited on Oct 21, 2021]. Available at: https://www3.paho.org/hq/index. php?option $=$ com_content $\&$ view $=$ article $\&$ id $=1350: \mathrm{me}$ didas-efectivas-control-tabaco\&Itemid $=1185 \&$ lang $=\mathrm{es}$

53. Guerrero-López CM, Muños-Hernández JA, MieraJuárez BS, Reynales-Shigematsu LM. Consumo de tabaco, mortalidad y política fiscal en México. Salud Publica Mex 2013; 55 (Suppl 2): S276-81. PMID: 24626704

54. Reynales-Shigematsu LM, Wipfli H, Samet J, RegaladoPineda J, Hernández-Ávila M. Tobacco control in Mexico: a decade of progress and challenges. Salud Publica Mex 2019; 61 (3): 292-302. https://doi. org/10.21149/9360

55. Malta DC, Stopa SR, Santos MAS, Andrade SSCA, Oliveira TP, Cristo EB, et al. Evolution of tobacco use indicators according to telephone surveys, 20062014. Cad Saude Publica 2017; 33 (Suppl 3): e00134915. https: / / doi.org/ 10.1590/0102-311X00134915

\section{Received on: 08/04/2021 \\ Reviewed on: 10/24/2021 \\ Accepted on: 11/11/2021}

Authors' contributions: JATD: conceptualization, formal analysis, writing - review \& editing. RRN: conceptualization, formal analysis, writing - review \& editing. 1spm: data curation, formal analysis, methodology, writing - original draft, writing review \& editing. AMB: conceptualization, design and planning, writing - review $\&$ editing 